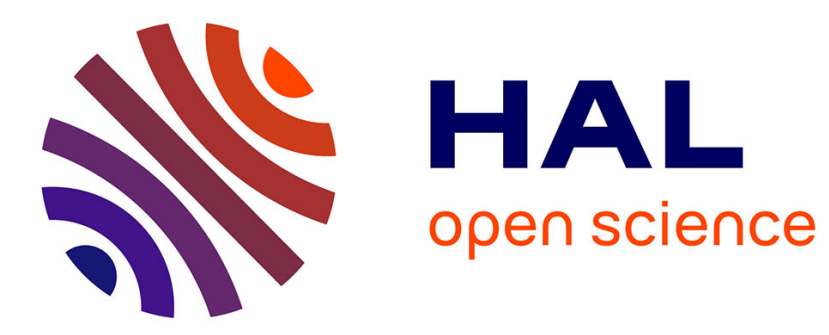

\title{
Service interactions and subjective well-being in later life
} Cécile Plaud, Samuel Guillemot

\section{To cite this version:}

Cécile Plaud, Samuel Guillemot. Service interactions and subjective well-being in later life. Journal of Services Marketing, 2014, 29 (4), pp.245-254. 10.1108/JSM-05-2014-0154 . hal-01381154

\section{HAL Id: hal-01381154 https://hal.science/hal-01381154}

Submitted on 4 May 2021

HAL is a multi-disciplinary open access archive for the deposit and dissemination of scientific research documents, whether they are published or not. The documents may come from teaching and research institutions in France or abroad, or from public or private research centers.
L'archive ouverte pluridisciplinaire HAL, est destinée au dépôt et à la diffusion de documents scientifiques de niveau recherche, publiés ou non, émanant des établissements d'enseignement et de recherche français ou étrangers, des laboratoires publics ou privés. 


\title{
Service interactions and subjective well-being in later life
}

\author{
Cécile PLAUD, ENSTA Bretagne, Brest, France \\ Samuel GUILLEMOT, Univ Brest, LEGO, Quimper, France
}

\begin{abstract}
Purpose. Due to increased life expectancies, people are experiencing major life events during aging (e.g. death of a spouse, serious disease, major health problems); events that lead to identity redefinition. In this context, the present research examines the positive and negative impact of service provider experiences on the process of identity adjustment and how they can lead to subjective well-being.
\end{abstract}

\begin{abstract}
Methodology. To gain more insight into this issue, a qualitative study was carried out that involved 37 in-depth interviews conducted with aging individuals who had experienced a major life event such as retirement and/or death of a spouse. In order to apprehend the diversity of consumption situations, we investigated daily consumption, hedonic consumption, and imposed services (e.g. health and funeral services) due to life events.

Findings. The findings suggest that service providers have an influence on consumer subjective well-being as regards relationships, growth and purpose in life, mastery and independence, and self-acceptance

Originality/value. Our contribution indicates that services play a role in maintaining and/or creating subjective well-being. By segmentation through social roles and facilitating access to services, providers must take into account the processes of normalcy and abandonment (déprise) among aging consumers in life transitions. They must also ensure that they support consumers with the lowest human capital (skills, level of education, income and social class).
\end{abstract}

To cite: Plaud, C. and Guillemot, S. (2015), Service interactions and subJective Well-being in Later LifE, Journal OF SERVICES MARKETING, 29(4), 245 - 254

Population aging is a worldwide demographic phenomenon that is attracting growing interest within the interdisciplinary academic research on old age, both at the individual and societal level (Moschis 2012). Indeed, well-being and successful aging are a relevant topic of interest in psychology (Baltes and Baltes 1990; Havighurst 1961). However, marketing researchers seem less preoccupied by well-being in old age, despite a growing number of studies on the aging consumer (Drolet, Schwarz and Yoon 2010). Our research intends to fill this gap. As service experiences can influence consumers' lives, partly through quality-of-life perceptions (Dagger and Sweeney 2006; Ostrom et al 2010), understanding how service providers can potentially influence well-being in old age is a pertinent topic of interest. Among well-being outcomes, we focus on subjective well-being (SWB), which is an individual's evaluation of his or her life that includes, amongst other things, life satisfaction and the pursuit of personal goals and objectives (Diener, Sapyta and Suh 1998).

Previous research on population aging has shown that quality of the service delivery is of major importance (Carstensen, Isaacowitz and Charles 1999; Moschis, Bellenger and Curasi 2003, Rosembaum 2006), however, it has also suggested that life events may influence seniors' service preferences (Grougiou and Pettigrew 2011). The conceptual framework of the life course paradigm seems particularly relevant here as it suggests that a major life event can lead to a change in life conditions, which requires adaptation and generates behavioral changes (Elder 1997; Moschis 2012). The more an individual ages, the more he/she is likely to experience a traumatic event that will lead to an identity adjustment. Such an event may be both objective (e.g. loss of loved ones, deterioration of physical capabilities) and subjective (e.g. feelings of vulnerability, shortening of the limited time horizon view). Within this context, the aim of our 
study is to understand how services help to create, improve or conversely reduce the elderly consumer's SWB following an aging-related traumatic life event (e.g. major illness or death of a close family member). The insight gained will contribute to improving the quality of life for both consumers and society as a whole (Ostrom et al 2010). Indeed, SWB is one of the three main measurements of societal quality of life, along with economic and social indicators (Diener, Oishi and Lucas 2003).

The present study is organized in three parts. The first part will situate the SWB concept in later life within the life course paradigm. This will be followed by a presentation of the research methodology (37 in-depth interviews conducted with older consumers aged 56 years and over in France). As our focus is on service encounters, our interview guidelines cover a wide spectrum of services: daily, chosen (e.g. leisure activities) and imposed (e.g. health). Then, from our results, we will propose a model that highlights four factors influencing SWB in old age: relationships, growth and purpose in life, mastery and independence, and self acceptance. The final part will present the theoretical and practical implications of the research and its limitations.

\section{THEORETICAL BACKGROUND}

Population aging is a major economic and societal issue. The emerging concept of successful aging (Baltes and Carstensen 1996) involves a state of physical and physiological well-being amongst the elderly and aims to define conditions and ways for individuals to preserve their health as long as possible. After defining well-being, we will investigate SWB in old age and situate it in the life course paradigm.

\section{Definition of subjective well-being in later life}

The Collins English Dictionary defines well-being as "the condition of being contented, healthy or successful", referring to welfare, good health, benefit, happiness and prosperity. At present, there is no consensus on a precise definition of well-being. However, previous research suggests that it is composed of at least three dimensions: (a) physical well-being: a good state of health and absence of disease or physical disorder (Diener and Oishi 2005); (b) mental wellbeing: both the presence of happiness and life satisfaction, and the absence of symptoms of depression or distress (Diener, Oishi and Lucas 2003); and (c) social well-being: the quality of interactions with others (Ryff and Singer 1998). This overview indicates that well-being could be approached through its objective components, but it is also emphasized by the subjective assessment of both quality of life and health (Wells et al 1989). For Diener, Sapyta and Suh (1998), subjective well-being is a person's evaluation of his/her life that involves between three and six dimensions. For instance, Laguardia and Ryan (2000) state that SWB concerns feelings of autonomy, self-efficacy and relations to others. For Ryff and Singer (1998), SWB refers to six universal dimensions: self-acceptance, positive relations with others, autonomy, environmental mastery, purpose in life and personal growth.

In the literature on aging, well-being is examined through the concept of successful aging (Havighurst 1961; Rowe and Kahn 1998) - a relatively recent concept involving both subjective and objective approaches (Pruchno, Wilson-Genderson and Cartwight 2010; Senges, Guiot and Malas 2013). Indeed, one research stream considers successful aging to be when an individual meets normative components defined in the literature, for example, the three characteristics of successful aging as defined by Rowe and Kahn (1998): low probability of disease and disease- 
related disability, high cognitive and physical functioning, and active engagement with life. Another research stream acknowledges that gains as well as losses are a critical part of the aging process. It then defines successful aging as an adaptation to those events (Baltes and Carstensen 1996).

This study follows the broad framework of Baltes and Carstensen (1996) and considers SWB to be a person's capacity to cope with gains and losses related to the aging process. At the individual level, life events are challenges that require adaptation and generate stress. Although negative experiences may dramatically diminish mental and physical health, they could be, "in some circumstances, the route to achieving deeper meaning and purpose and heightened mastery" (Ryff and Singer 1998).

\section{Adaptation to life events and subjective well-being}

The life course paradigm suggests that changes to life conditions in the form of life-event experiences create physical, social, and emotional demands and circumstances that people must deal with (Moschis 2007), hence its structure around stability and change issues. Life events are transitions that impact social position and individuals' comprehension of the world. At the same time, they are particular moments in life in which individuals may re-negotiate their identity (Caradec 2004). Indeed, "life transitions are occurrences that elicit changes in an individual's perceptions (of self, of the world) and in the organization of his/her roles, resources and central relationships" (Hopkins, Roster and Wood 2006). This view supports the idea that there are both negative and positive impacts inherent in the aging process and as such, they could be considered as an "epiphany": "a moment which is a turning point in the life course" (Denzin 1989). The development and changes in patterns of thought and action may be viewed as an outcome of adaptation, which entails the processes of socialization (normative perspective), stress and coping responses (stress perspective) and development/growth or decline (human capital perspective) (Moschis 2007).

Normative perspective. The life course is viewed as a set of multiple social roles and it is considered that an individual's behavior and interactions with others can be explained at the social level. From this sociological point of view, a social role is defined as "a pre-established pattern of actions" that is implemented during interactions (Goffman 1959). The aging process is associated with particular social roles resulting from different life events. These events - such as retirement, birth of a grandchild or death of a spouse - serve as markers of the transition into important social roles, e.g., retiree, grandparent, widow(er) (Elder, Kirkpatrick Johnson, and Crosnoe 2003). Aging people enact social roles according to social expectations and the impressions they wish to give to others (Goffman 1959). Schewe and Balazs (1992) identify some aging-related social roles: empty-nester, caregiver, retiree, grandparent, widowhood and cohabitation or remarriage. Although some of these roles are positively portrayed (i.e. grandparent or caregiver), widowhood is portrayed as a negative role, and there are diverse retirement experiences. As such, the diversity of social roles during the aging process must be taken into account. At the same time, the normative perspective allows us to understand that social roles lead to identity changes and redefinition of the self (Caradec 2004), which could have a potential impact on SWB.

Stress perspective. Life events, whether negative or positive, create a disequilibrium that requires adaptation (Moschis 2012). Coping efforts, according to Lazarus and Folkman (1984), 
involve the cognitive and behavioral strategies used to manage the feelings produced by expected and unexpected events. Behavioral changes could occur during the coping process, one example of which is consumption behavior (Andreasen 1984; Lee, Moschis and Mathur 2007; Pavia and Mason 2004; Schouten 1991). Following the SOC (selective optimization with compensation) model of Baltes and Baltes (1990), successful aging depends on the ability to maximize gains and minimize losses. Three coping strategies form part of this process: selection, optimization, and compensation. Perception, either negative or positive, of a life event is also a key dimension in how individuals anticipate the transition into a new social role and the adaptation strategies they adopt (Hopkins, Roster and Wood 2006).

Human capital perspective. This refers to the resources, qualifications, skills and knowledge that people acquire during the life course. Events and roles are viewed as sources of intellectual growth and enable the individual to act in new ways (Moschis 2012). This capital accumulated over an individual's lifetime inevitably shapes thoughts and actions. Indeed, some personality traits, such as locus of control, self-esteem or dispositional optimism, could explain individual differences in the level of SWB (Diener, Oishi and Lucas 2003). Growth and change in the individual's human capital are influenced by individual and environmental factors viewed as hierarchical, and interrelated structures ranging from the macro- (e.g., culture) to the micro- (e.g., family) level setting (Moschis, Mosteller and Kwai Fatt 2011). As such, previous studies highlight that there are different perceptions of well-being both between nations and between ethnic groups within nations (Diener, Oishi and Lucas 2003). More generally, all of the resources available to individuals (time, finance, social support, attitude, etc.) influence how they deal with life transitions (Hopkins et al 2014).

\section{METHODOLOGY}

Given the limited previous research on how service interactions impact SWB in old age, we adopted a qualitative approach to identify and explore how aging individuals perceived service interactions. The sample comprised 37 French older consumers aged between 56 and 88 years. France is representative of Western countries as regards both service levels and population structure. According to the French National Statistics Office (Insee), the over-60s group currently represents $23 \%$ of the population and should account for over one third of the population by 2060 (Blanpain and Chardon 2010).

\section{Sample}

All respondents were retirees. This threshold was selected because there is a general consensus amongst health, psychology and marketing experts that retirement marks the beginning of "old age" and leads to an identity adjustment (Bresay 2004; Fry 1990; Guiot 2006). Furthermore, one of our criteria was that a couple of years prior to being interviewed, informants must have experienced one of the events listed by Holmes and Rahe (1967) in the Social Readjustment Rating Scale. These events (i.e. death of a spouse, serious disease or major health problems) generate stress and vulnerability and require an identity adjustment. At the time of the study, five informants were undergoing grief therapy - sessions designed to prevent loneliness after the death of a loved one and provide emotional support and coping strategies, including self-help groups, leisure activities, and nutritional information. Finally, our sample varies in terms of level of disposable income or previous occupation (i.e. former doctor, teacher, homemaker, tradesperson). Appendix A provides a summary profile of the 37 respondents. 


\section{In-depth interviews}

The two authors served as interviewers for the data collection process. Semi structured interview questions were used. The objective of the interviews was to situate respondent perceptions of service interactions. Different consumption contexts were investigated to apprehend the diversity of service situations. The service industries most frequently cited by respondents were public administration, insurance, and banking, which are all services imposed by the life event, and reference was also made to leisure activities or travel, which are nonimposed services. Finally, respondents were encouraged to talk about hedonic consumption (leisure or cultural services). All interviews were conducted at the participant's residence and lasted between 45 and 240 minutes.

\section{Data analysis}

Interviews were recorded with respondent consent and fully transcribed by the authors; the data collected represented approximately 700 pages of retranscription. An analysis was conducted following an iterative process of data coding, categorization and abstraction (Mc Cracken 1988). Both authors separately read each transcribed interview, noting any specific SWB- and service interaction-related themes. The coding process used the prior theoretical background and was enriched with emergent concepts. The coding data were compared, contrasted and reduced in order to establish a unified pattern of analysis for SWB in later life. Finally, the research team discussed these themes and questioned their relationship to the consumption of services.

\section{FINDINGS}

The collected data highlighted both positive and negative service interactions. When we situated these results in the respondents' life context, we were able to understand their impact on SWB for four dimensions. The first one, "relationships", had already been highlighted by previous research carried out for the present study. The others were "growth and purpose in life", "mastery and independence", and "self-acceptance" (Figure 1).

Figure 1. The impact of service interactions on subjective well-being (SWB) following a major life event in later life

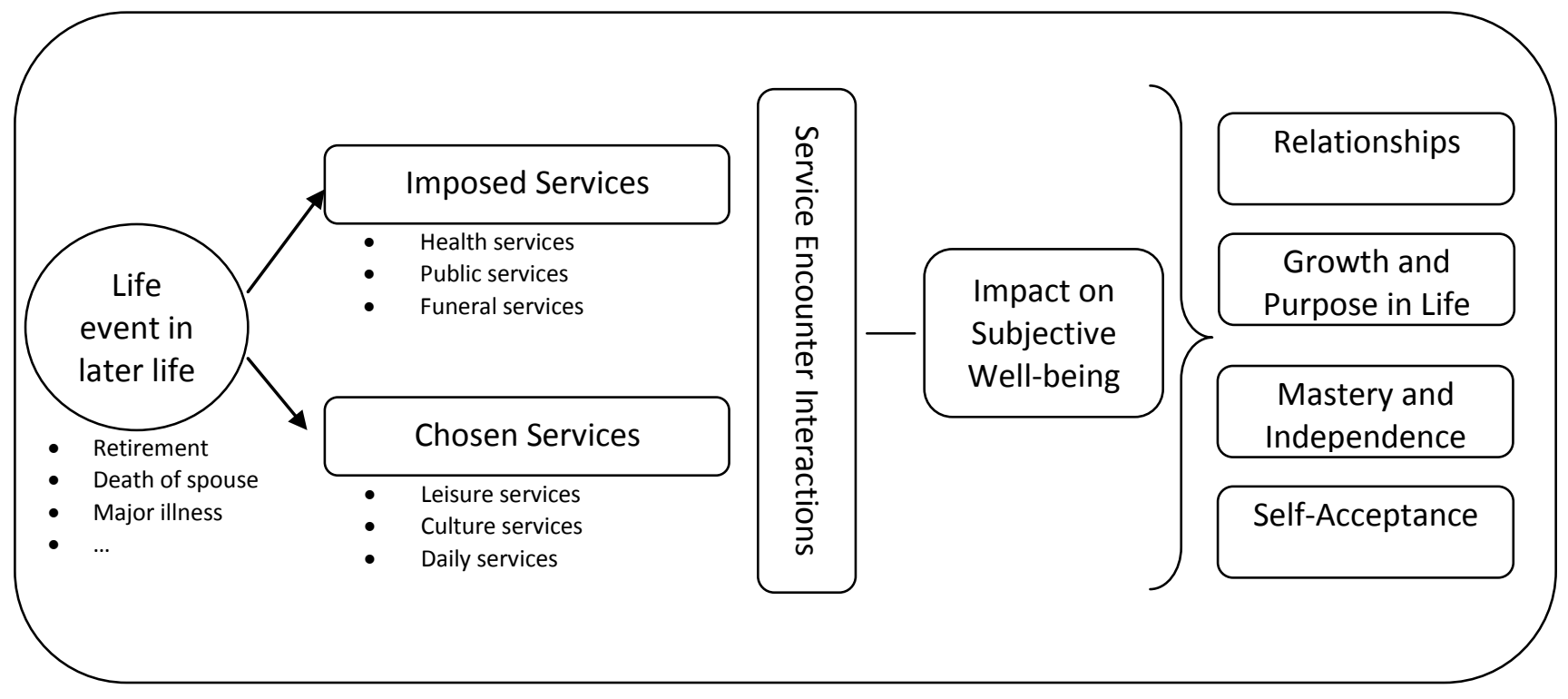




\section{Relationships}

Findings indicate that services could play a role in the creation and maintenance of relationships. This may be particularly important at a time when identity is challenged by life events. The role that services play in relationships was identified in two complementary ways: on the one hand, mundane relationships with service staff, and on the other, relationships between the consumers themselves.

Mundane relationships with service staff. Service staff play an important role in the creation of social links, even in mundane and everyday situations. Marion (death of spouse) appreciated that the man from the Ecomarché supermarket adopted an empathic attitude: "This man knows about my husband. He told me, when you need something, if you need any help ... I don't know. He seemed to take an interest in me, it's important, I think it's important". In this case, we noted that people are more sensitive to empathic attitudes, particularly when the service is delivered at home. Edith (death of spouse) confessed that when her home cleaner arrives: "Somebody's there, we have fun" and she appreciated this relationship. Geneviève (death of spouse) said that when her home cleaner arrives each week, she "restarts" and like Edith, appreciates this relationship. We noted that beyond their instrumental function, domestic services fulfill an affective function to which providers give less prominence. For older people who sometimes experience loneliness, domestic service staff play an important role in the creation and maintenance of relationships and thus impact SWB.

Relationships between customers. Services, particularly leisure ones, also contribute to creating and maintaining relationships. At the same time, they help older people to find new reference groups in which they may redefine themselves following the life event. Paul (recent retirement and divorce) started to go to the local cafe to compensate for a diminished social network: "I was used to seeing people as part of my work [...] there, I go there to have my morning coffee, I don't always join in the conversations but I like it that there's some background noise". Sylvie (retirement, death of both parents, last child to leave home) greatly appreciates these types of services as they allow her to strengthen family links and to remain present in the family memory: "I know I'm going to die in a couple of years ... I do think about it, I won't go as far as to say that I feel anxious, but I need to know I will be remembered [...]. I've just got back from a trip with my grandson. It was great! We had some really precious moments, we did a lot of activities, and we talked a lot. He's now 8 years old and at that age you keep memories, he will remember me all his life now. You're not completely dead if your memory lives on with other people". Claire (death of spouse) is very diligent with her leisure activity (painting): in her mind it is a form of "work" that helps her to maintain social ties (she lives in a rural area) and to structure her schedule.

Following the death of a spouse, some respondents expressed the need to meet people in the same situation, and for those attending the bereavement counseling sessions, this contact was a means of fulfilling this need. Yvonne, Simone, Annette or Jeanne (death of spouse) gained satisfaction from being able to talk and listen to other widows and widowers and some of them have remained friends after the sessions have finished. In their mind, it helps them to accept their new situation and their new social role because they realize that they are not alone in coping with this traumatic experience: "I told myself that I wouldn't be alone, I would listen to others and see 
if they feel ... the same, because sometimes, I mean, sometimes you feel really ... like you're not normal ... how do you say that? ... You feel so alone, you've got so many things to do, and you're really not doing terribly well yourself" (Simone).

\section{Self-acceptance}

Service interactions play an important role during these life events for two reasons. Firstly, service encounters have an impact on the meanings that respondents give to the event itself and secondly, they are a way towards self-definition according to social roles.

Meaning of the event and service interactions. Because people need to give meaning to their life, service interactions form part of this process. Sometimes, respondents blamed doctors or medical services for the death of their spouse. For Marion (death of spouse), doctors, or the health care system in general, are part of a social system that did not help her husband: there is no research into his particular illness and she felt abandoned. This very specific illness context is still difficult to talk about two years later. Gisèle (death of spouse) explained that for her husband "the 'medical machine' didn't work". According to Yvonne and Edith (death of spouse), the doctors did not listen to them and this lack of empathy was very difficult to accept. Confronted with her husband's suffering, Edith spoke to the doctors and made a request for euthanasia. Two years later, she still feels very angry about it and she did not realize at the time that euthanasia is prohibited; the doctors would have been acting illegally. During Annette's interview (death of spouse), she repeatedly talked about the hospital: "It was not a very friendly place ... never a hello, no consideration ... it was awful, really awful". She believes that the hospital - the "medical machine" - was unable to save her husband and she cannot come to terms with this. On the contrary, positive interactions with and feelings towards health care staff are a key component for coping well after the death. For Jeannette and Simone (death of spouse), their GP offered reassurance and support just before or after the death of their spouse, and this meant a great deal to them.

The meanings of the death also could be positively or negatively influenced depending on funeral service experiences. Nathalie (death of spouse) was satisfied by funeral home services: "Well, when he died, the funeral home did everything, everything, we didn't have to deal with a thing. So, we paid, we set our minds at rest, it was done, and we didn't have to see to anything". This satisfaction is part of her serenity. However, for Marion and Jeannette (death of spouse), their experiences were negative as their beliefs were challenged. Jeannette explained: "When someone dies, you have to pay immediately otherwise they do not rest in peace". Although she admitted that such a belief is "ridiculous", for unknown reasons, her own payment was delayed. More than one year later, this fact remains particularly difficult for her. For Marion, the most "terrible" moment was when the funeral staff gave her the urn that was "still warm". Two years after the death, she still cries when she remembers this. In her case, it was difficult to accept as the cremation was her husband's wish but it went against her own beliefs.

Finally, some respondents tried to give meaning to the death and agreed to attend bereavement counseling sessions proposed by their pension providers. They explained that the sessions helped them to give the death meaning. In the cases of Gisèle and Simone, it helped them to "carry on, to move forward" and to understand the grieving process. As Marion said, "I didn't know anything about stress, we had a discussion, talking about what we had to accept, to work on acceptance ...". One respondent who attended these sessions expressed how difficult it was for her 
afterwards: "When the program finished, I was sick, I stayed in bed for two whole days and two nights, I couldn't stand up, and I was ... I had to take medication because I felt really bad" (Geneviève). Perhaps it was the prospect of returning home alone that explains her reaction. However, we may call into question how the pension company could have been more present after the bereavement counseling by offering a personalized post-service support.

Self-definition, social roles and service interactions. When identity is challenged by a life event, older people tend to redefine themselves. Leisure and art activities, and more specifically senior citizens clubs play an important role. Such clubs are the point from which some respondents define themselves as aged people or as different from aged people: "There is a very good club, I mean, the leisure or art club for instance, it's quite interesting, and there are different ages from 20 to 90 years old, it's really good. There is another club, a senior citizens club, and the oldest person is 96 years old - I do not go there" (Jeannette, 79 years old). What seems to be particularly important for respondents is the club's age mix: "Even though I was born here, I do not go to the local senior citizens club. Some of the people there are 80 years old or over and they talk a load of drivel. When you're with young people, it keeps you on your toes" (Marion, 67 years old). Subjective age helps us to understand how people define themselves - their personal definition of the Self: "I have a young personality, I feel like a woman who is 58 or 60 years old" (Marion).

\section{Growth and purpose in life}

The data collected highlighted that consumption of leisure and culture services is a way of planning new projects, enriching oneself and coping with life's events and difficulties. Jean (major personal illness) expressed this very well: "Of course I have projects [...] if you don't dream, you die". Retirees can devote themselves to new projects or ones that may have been planned a long time ago but were delayed due to lack of time. Many products or services enable older people to realize these plans, such as dance, cooking, and sewing classes, or courses at Universities of the Third Age (U3As). For instance, Yvette (retirement, last child to leave home) is learning a new language: "I'm learning Spanish in a community center. I started two years ago when the children left home; there's a big gap when children leave home ..." At the same time, she attends history classes as an associate student at university: "Now that's something I really like. I have always been fascinated by history, so I used to say that when I had more time, I would enroll on a university course".

Services and service encounters play an important role in the growth and purpose in life dimension of SWB. Indeed, service experiences can be both positive and negative in that they could play a supportive role or hinder these efforts.

Supportive role of service encounters. Our data highlight that service encounters may support and then help informants at different moments in their life experiences. On the one hand, a welladapted environment facilitates the realization of projects. Talking about her associate student experience, Yvette (retirement, last child to leave home) said: "I have fun. I go to the lectures as well as the classes, I attend the same course as students but I don't sit the exams. The lecturers are very kind, very understanding, and they do their best to support us. For example, sometimes 
it's difficult because I don't have the same educational background and academic qualifications, but I am heartened by the teachers' and the students' solidarity. It's great'. Generally, these experiences allow older people to feel alive despite the uncertainties of life. Joelle (death of a close friend) wanted to cope with her frustration after her best friend died of cancer 10 months ago. In her case, traveling and hedonic consumption appear as coping strategies: "To cope with the idea of death, I'm reading, writing, enjoying life, traveling, painting, doing calligraphy, walking, swimming every morning at $7 \mathrm{am}$ and so on. I'm planning a pool party for my $80^{\text {th }}$ birthday! All my friends will be in the water at 8 am and then we'll have a giant brunch!"

On the other hand, services offer respondents the right conditions to achieve some of their meaningful goals. For instance, Gisèle (death of spouse) is pursuing a project that is personally meaningful and which she wanted to do before she died: becoming a "homestay host" for foreign children in France. Her Catholic faith, the positive image of the grandmother role as well as the desire to "take care" of someone encouraged her in this project. Denise (death of spouse) helps her neighbor's children with their homework. During the interview, she said that her own children accused her of not having encouraged them in their studies. Taking care of a child, especially through homework help, is partly a way to make up for such reproaches. Geneviève (death of spouse) was a former nurse and still wants to help and care for people. Since her retirement, she has undertaken personal training in a "complementary" medical technique" called reiki. For her, it is way of giving meaning to her own life by being useful to somebody else. These respondents expressed differently that, in spite of widowhood or retirement and whatever their age, they intend to find purpose in their life and to pursue meaningful activities.

Service encounters as an impediment. Although service encounters can aid and facilitate retirees' plans, they can also make it more difficult when the objective is more personal or is not yet catered for by providers. Claude (retiree, major personal illness) worked in a town hall near Paris. He was responsible for organizing the construction of a Shoah Memorial in his town: "For this purpose, we worked over 5-6 years on the issue, reading lots of documents and doing research to finally identify 350 names". After his early retirement due to health reasons, reporting on the atrocities committed during WWII was kind of therapeutic: "I worked on it for 2-3 years; I visited the National Library $(\mathrm{BnF})$ archives. I combed the press, the BnF has all the newspapers. My home is now full of archive boxes. I spent three months writing day and night! I wanted to adopt a scientific approach".

But Claude feels disappointed as he cannot find any recognition for his work: "I have contacted twenty publishers [...] I contacted journalists and even historians, but nothing, I can't find a home for my story! [...] They've got no interest in this dark side of our past, they are still in their narcissistic culture and they will never recognize work on these topics".

\section{Mastery and independence}

Our findings suggest that during life events, identity and SWB are challenged partly because older people no longer control their environment. At the same time, it appears that services are a way to express and assert independence.

Mastery. Sometimes, because informants were unaware of particular processes or their rights, they felt weakened or angry. For Elise, after the death of her husband, she had to "fight" with the 
public administration: "There are mistakes and I still receive papers with his name on, it's still a struggle". Claire (death of spouse) expressed resentment towards insurance companies: "We need to know what our rights are because we don't necessarily know them automatically. After his death, a notification had to be made for the life insurance, I didn't know this and the deadline had elapsed!". Martine (death of spouse) was disappointed because "There are a lot of things to change but nobody ever told you that!". Our respondents feel ignorant precisely at a time when they must cope with a very traumatic event. In such situations where they could no longer control their environment, our informants showed their lack of knowledge, which impacted their subjective well-being.

Independence. Some respondents discovered that following the death of their spouse, they enjoy making decisions by themselves. Geneviève sold all the furniture in her house because now she wants to "have fun". This furniture symbolized an old identity, her spouse's identity, and these pieces of furniture are "useless" now. As a widow, she wants to reconnect with the young woman she once was. Gisèle and Elise explain that since the death, they appreciate making decisions alone: Gisèle changed her kitchen and now it "suits her", whereas Elise reorganized her home according to her own tastes. Jocelyne "does what she wants", whereas before she "lived for her husband". Each of these respondents explained differently that the death of their spouse was an event that has led them to discover their capabilities. In this process of identity reconstruction, service providers appear as an external resource, fulfilling the role of instrumental support and enabling respondents to do things "by themselves": "You've paid for it and therefore, you're independent; if it is the family ... it must be external people because that way you keep your freedom" (Geneviève). By using external services, individuals can retain their freedom, which is particularly important at a time when identity is being challenged.

\section{DISCUSSION AND MANAGERIAL IMPLICATIONS}

The results of our study enable a model to be put forward showing how chosen or imposed service encounters can impact the subjective well-being of older consumers following a life event. This can be seen in four ways: facilitating the self-acceptance process, enhancing relationships, allowing personal growth and the pursuit of individual purpose in life, and/or providing a feeling of mastery and independence. While previous research has underlined the importance that seniors give to the relational aspects of service encounters (Grougiou and Pettigrew, 2011), our study confirms their important role in life transitions, and extends these studies by highlighting the consideration of three elements: (i) the concept of consumer normalcy applied to the context of life transitions in the aging process, and (ii) the role that service encounters play in déprise, the process of adjustment inherent in aging. (iii) Finally, in continuing Hopkins' work (Hopkins et al. 2014), the present study helps to specify how resources (social class, level of education, income) impact capacity to manage service encounters during life transitions.

Our respondents expressed that the life event, by reconfiguring social roles, feeds particular expectations, either through their connection with similar people (homophily), Gentry et al. 1995) and/or the fact that through others, they can send out a positive image of themselves. This is particularly salient for the SWB dimensions of relationships and self-acceptance. Although the importance of the roles is strongly emphasized by the normative perspective of the life course paradigm, using the concept of normalcy (Baker 2006) means that it is possible to go even further 
and to understand how service encounters will impact SWB among older consumers. In accordance with this concept, our study suggests that services could help older people to (re)define themselves in a way that is acceptable both for themselves and others (Baker 2006). Besides consumption experiences, other service contexts could make it easier for older people to recover their normalcy. At the same time, results suggest that although identity is partly challenged by the life event, our respondents still expressed their desire to control their environment. In line with the concept of normalcy, our informants intended to display their competence, "I am in control" (Baker 2006). This capability also depends on service providers (i.e. public administration or insurance) and highlights their role in enabling older people to exert this control.

To this effect, a segmentation of older consumers based on social roles facilitates the self acceptance process. In this regard, respondents in the present study coping with the death of a spouse said that the bereavement sessions helped them understand that their reactions to the death were "normal" and therefore, that they were "normal people". Thus, we recommend a life eventbased segmentation in order to propose adapted offers that meet the target population's expectations and needs. This applies equally to the "known" roles of aging (widow(er)/retiree), and the lesser known roles in which service providers could play a part (the role of caregiver to ensure inter-generational cohesion, or that of grandparent to transmit family history and heritage). The challenge lies in offering tailor-made services that empower the target population and enable these individuals to invest more in each of these social roles.

Our results show that older consumers will be even more sensitive to the type and the quality of service relationships in response to life experiences. Moreover, some of them will use the services in their pursuit for growth and purpose in life. These two connected elements could be interpreted in line with the concept of abandonment. Although previous research on stress highlights both the positive and negative impacts on SWB, the results of the present study underline how important it is to consider aging through a wider approach that is specifically adapted to aging individuals. In this respect, "abandonment" is an emerging concept in sociology that could help us to understand our findings in a complementary manner. It involves the process of identity (re)construction during the aging process, defining a negotiation process between an individual and the world that is triggered by aging. In other words, it is an "economy of force" process in which individuals prioritize in order to focus resources on meaningful activities (Clément and Membrano 2010). In their relationships, respondents make "choices" according to what is significant and important for them: whilst pursuing meaningful activities, some of them gave priority to what was personally meaningful.

Service providers can play a facilitating role in this process by supporting older consumers in their choice of activities and relationships that are meaningful to them. A key area of development for service providers is therefore to work on service access conditions. Recognizing that seniors have the right to carry on making plans, and providing them with the means to complete such projects is now a significant comparative advantage. A key point here is funding. Indeed, very often service providers refuse to offer funding or insurance to older consumers because of the associated risk of reduced life expectancy. Nevertheless, in France, 87 years is the average age at which dependence becomes more frequent, but not necessarily systematic (Spini, 2012). Of course, service providers cannot respond favorably to all personal plans, but even so, advisors should be able to justify refusals without stigmatizing the older population. This leads to a second area of development: improving staff training to raise awareness of how their actions 
and words can affect their clientele. In this respect, the attitude of first contact staff has a determining impact both on feelings of well-being and the evaluation of the service. Therefore, we recommend "codifying" social relations with defined behavioral scripts, for example, by noting any new developments during the first contact and preparing refusals, for example.

Finally, respondents of the present study who are working class and express negative emotions towards service staff, tend to consider that State and health services are part of a "system" that is beyond their control, which illustrates the model's self-acceptance dimension. In the same way, respondents with a lower level of education feel more vulnerable and ignorant of public administration procedures and paperwork, especially after the death of their spouse (mastery and independence dimensions of the model). This does not mean that they are unable to cope with these procedures, but that their SWB could be impacted if they do not find appropriate answers and assistance from service providers. Although most previous studies accept that factors such as level of education, income or background account for only a slight variance in SWB measurements (Diener, Oishi and Lucas 2003), our findings suggest that social class could influence how older people interpret and make sense of life events.

This raises the question of how to support older consumers and contribute to good conditions for their well-being. One solution could be to offer these consumers all-inclusive "life event" options. For example, a kind of "one-stop-shop" system would be appropriate to facilitate these approaches that are sometimes long and complex. This would involve cooperation between the different service providers. In the case of bereavement, for example, public services and/or complementary services responding to the same need could be connected to offer a unique interface. This requires collaboration and close links among the complementary service providers. However, it should be noted that this feeling of control must be accompanied by an element of choice so that individuals are left with a feeling of independence.

\section{CONCLUSION}

The objective of this paper was to gain an understanding of how service encounters influence SWB in later life. Following the life course paradigm, our results highlight that service encounters may impact the normative, stress and human capital perspectives. Service providers should be aware of this impact on SWB, particularly in the case of vulnerable people. Improving SWB at the individual level may improve societal quality of life (Diener, Oishi and Lucas 2003).

There are various limitations to the present study. Firstly, two aging-related life events widowhood and retirement - are overrepresented in our data set. Indeed, widows comprise around half of our sample, which explains why the majority of quotations are from women. Although these two events are particularly representative of aging, other ones also need to be taken into account, such as children moving out of the family home or relocation. Secondly, we only focused on the viewpoint of the aging consumer. Executives and employees' viewpoints, as actors, may be collected to gain a deeper understanding of the phenomena. Thirdly, in order to understand the impact of life events on subjective well-being, we need to examine how life events may have a long-term differential impact on well-being. Some research highlights that only recent events impact SWB (Suh, Diener and Fujita 1996), but this cannot be generalized to cover aging individuals, for whom life events occur at a time when their physical health is 
challenged by the effects of biological aging. A very stressful and traumatic event in old age, such as the death of a spouse, increases the likelihood of becoming dependent (Mallon 2003).

From these insights, three avenues for future research can be suggested. The first one relates to conducting the study with a younger population. Indeed, this article focuses on consumers in later life, but other populations may also be prone to vulnerability following traumatic life events. On the contrary, the second avenue concerns a higher level of vulnerability among the aged (decreased decision-making ability, dependency, etc.). Insights gained from new conceptualizations relevant to the study of older consumers' vulnerability may serve to better inform the stakeholders involved in public policy initiatives (Moschis, Mosteller and Kwai Fatt 2011). Finally, a multi-method investigation could increase understanding of the transition process and individuals' diverse appraisals of life transitions, which in turn, could provide solutions to marketing issues (Hopkins et al 2014).

\section{REFERENCES}

Andreasen, Alan R. (1984), "Life Status Changes and Changes in Consumer Preferences and Satisfaction", Journal of Consumer Research, 11 (3), 784-794.

Baker, Stacey M. (2006), "Consumer Normalcy: Understanding the Value of Shopping through Narratives of Consumers with Visual Impairments", Journal of Retailing, 82 (1), 37-50.

Baltes, Paul B. and Margaret M. Baltes (1990), "Psychological Perspectives on Successful Aging: The Model of Selective Optimization with Compensation", In Successful Aging: Perspectives from the Behavioral Sciences, Ed Baltes Paul B. and Margaret M. Baltes, New York: Cambridge University Press, 1-34.

Baltes, Margaret M. and Laura L. Carstensen (1996), “The Process of Successful Aging”, Aging and Society, 16, 397-422.

Blanpain, Nathalie and Olivier Chardon (2010), "Projections de Population 2007-2060 pour la France Métropolitaine", Insee Résultats-Société n¹17(December).

Bresay, Claude (2004), "Vieillir, Mourir âgé en Institution", Etudes sur la Mort Thanatologie, $126,37-42$.

Caradec V. (2004), Vieillir après la Retraite. Approche Sociologique du Vieillissement, Paris, PUF Sociologie d'Aujourd'hui, 240 p.

Carstensen, Laura L.; Derek M. Isaacowitz and Susan T. Charles (1999), "Taking Time Seriously: A theory of Socioemotional Selectivity", American Psychologist, 54 (3), 165-181.

Clément, Serge and Monique Membrano (2010), Expériences du Vieillir : Généalogie de la Notion de Déprise, in ed Carbonnelle, Sylvie, Penser les Vieillesses, Regards Anthropologiques et Sociologiques sur l'Avancée en âge, Seli Arslan, 109-128.

Collins English Dictionary, on-line edition, http://www.collinsdictionary.com

Dagger, Tracey S. and Jilian C. Sweeney (2006), "The Effect of Service Evaluations on Behavioral Intentions and Quality of Life", Journal of Service Research, 9 (1), 3-18.

Denzin, Norman K. (1989), Interpretive Biography, Qualitative Research Method Series, Sage University Paper

Diener, Ed and Shigehiro Oishi (2005), "The Nonobvious Social Psychology of Happiness", Psychological Inquiry, 16 (4), 162-167.

Diener, Ed, Shigehiro Oishi and, Richard E. Lucas (2003), "Personality, Culture, and Subjective Well-Being: Emotional and Cognitive Evaluations of Life", Annual Review of Psychology, 54 (4), 403-425. 
Diener, Ed, Jeffrey J. Sapyta and, Eunkook Suh (1998), "Subjective Well-Being is Essential to Well-Being", Psychological Inquiry, 9 (1), 33-37.

Drolet, Aimee, Norbert Schwarz and, Carolyn Yoon (2010), The Aging Consumer - Perspectives from Psychology and Economics, Routledge

Elder, Glen H. Jr (1997), "Life Course and Human Development", In Handbook of Child Psychology ed Damon, William and Richard M. Lerner, New York: John Wiley \& Sons, 939991.

Elder, Glen H. Jr., Monica Kirkpatrick Johnson, and Robert Crosnoe (2003), "The Emergence and Development of Life Course Theory", in Handbook of the Life Course, ed Mortimer, Jeylan T. and Michael J. Shanahan, Plenum Publishers, 3-10.

Fry, Christine L. (1990), "Cross-cultural Comparisons of Aging”, in Gerontology: Perspectives and Issues, ed Ferraro, Kenneth F., Springer Publishing Co, New York, 129-146.

Gentry, James W., Patricia F. Kennedy., Catherine Paul and, Ronald P. Hill (1995), "Family Transitions during Grief: Discontinuities in Household Consumption Patterns", Journal of Business Research, 34 (1), 67-79

Goffman, Erving (1959), The Presentation of Self in Everyday Life, Anchor Books.

Grougiou, Vassiliki and Simone Pettigrew (2011), "Senior Customers' Service Encounter Preferences", Journal of Service Research, 14 (4), 475-488.

Guiot, D. (2006), "Un Cadre d'Analyse du Processus de Vieillissement et de son Influence sur le Comportement d'Achat du Consommateur Agé”, Recherche et Applications en Marketing, 27 (1), 57-79.

Havighurst, Robert J. (1961), "Successful Aging”, The Gerontologist, 1 (1), 8-13.

Holmes, Thomas H. and Richard H. Rahe (1967), "The Social Readjustment Rating Scale", Journal of Psychosomatic Research, 11 (2), 213-218

Hopkins, Christopher.D., Catherine A. Roster and, Charles M. Wood (2006), "Making the transition to retirement: appraisals, post-transition lifestyle, and changes in consumption patterns", Journal of Consumer Marketing, 23 (2), 89-101

Hopkins, Christopher D., Charles Wood, Jennifer Siemens and Mary Anne Raymond (2014), “A multi-method investigation of consumer response to marketing activities during life transitions", Journal of Consumer Marketing, 31, 1, 39-53

Laguardia, Jennifer G. and, Richard M. Ryan (2000), "Buts Personnels, Besoins Psychologiques Fondamentaux et Bien-être : Théorie de 1'Autodétermination et Applications", Revue Québécoise de Psychologie, 21(2), 281-304.

Lazarus, Richard. S. and Folkman Susan (1984), "Stress, Appraisal and Coping”, New York, Springer Publishing Company

Lee, Euehun, George P. Moschis and, Anil Mathur (2007), "Stress, Coping and Consumer Preferences: a Two-way Transitional Event History Analysis", International Journal of Consumer Studies, 31 (4), 428-435.

Mallon, Isabelle (2003), Des Vieux en Maison de Retraite : Savoir Reconstruire un Chez-soi, Empan, 4, 52, 126-133

McCracken, Grant (1988), The Long Interview, Thousand Oaks, CA: Sage Publications

Moschis, George P. (2007), "Life Course Perspective on Consumer Behavior", Journal of the Academy of Marketing Science, 35 (2), 295-397.

Moschis, George P. (2012), "Consumer Behavior in Late Life: Current knowledge, Issues, and New Direction for Research", Psychology and Marketing, 29 (2), 57-75. 
Moschis, George P., Danny Bellenger, and Carolyn Curasi (2003), "Financial Service Preferences and Patronage Motives of Older Consumers" Journal of Financial Service Marketing, 7 (4), 331-340.

Moschis, George P., Jill Mosteller and, Choong Kwai Fatt (2011), "Research Frontiers on Older Consumers' Vulnerability”, Journal of Consumer Affairs, 45 (3), 467-491.

Ostrom, Amy L., Mary Jo Bitner, Stephen W. Brown, Kevin A. Burkhard, Michael Goul, Vicki Smith-Daniels, Haluk Demirkan, and Elliot Rabinovich (2010), "Moving Forward and Making a Difference: Research Priorities for the Science of Service”, Journal of Service Research, 13 (1), 4-36.

Pavia, Teresa M. and Marylys M. Mason (2004), "The reflexive Relationship between Consumer behavior and Adaptive coping", Journal of Consumer Research, 31 (2), 441-454.

Pruchno, Rachel A., Maureen Wilson-Genderson and Francine Cartwright (2010), "A Two-factor Model of Successful Aging", The Journals of Gerontology: Series B Psychological sciences and social sciences, 65 (6), 671-679.

Rosenbaum, Mark S. (2006), "Exploring the Social Supportive Role of Third Places in Consumers' Lives", Journal of Service Research, 9 (1), 59-72.

Rowe, John W. and Robert L. Kahn (1998), Successful Aging, New York: Random House

Ryff, Carol D. and Burton Singer (1998), "The Contours of Positive Human Health", Psychological Inquiry, 9 (1), 1-28.

Schewe, Charles D. and Anne L. Balazs (1992), "Role Transitions in Older Adults: a Marketing Opportunity", Psychology and Marketing, 2, 85-99

Schouten, John W. (1991), "Selves in Transition: Symbolic Consumption in Personal Rites of Passage and Identity Reconstruction", Journal of Consumer Research, 17 (4), 412-425.

Senges, Eloïs, Denis Guiot and Ziad Malas (2013), "Every Man to his Own Aging Well: The Desired Aging Well and its Influence on the Consumption of People Aged from 50 to 65", Actes du 29ème Congrès de l'Association Française de Marketing, La Rochelle, France (1617 May)

Spini D. (2012), Les ressources qui tiennent la vulnérabilité à distance au grand âge, « Parcours de vulnérabilité au grand âge : pratiques sociales et régulations juridiques »Université de Bretagne Occidentale, Brest, France.

Suh, Eunkook; Ed Diener and, Frank Fujita (1996), "Events and Subjective Well-Being: Only Recent Events Matter", Journal of Personality and Social Psychology, 70 (5), 1091-1102.

Wells, Kenneth B., Anita Stewart, Ron D. Hays, Audrey Burnam, William Rogers, Marcia Daniels, Sandra Berry, Sheldon Greenfield, and John Ware (1989), "The Functioning and Well-being of Depressed Patients: Results from the Medical Outcomes Study", The Journal of the American Medical Association, 262 (7), 914-919. 


\section{Appendix A. Interviewee list}

\begin{tabular}{|c|c|c|c|}
\hline Name & Gender, age & $\begin{array}{l}\text { Former situation } \\
\text { (before retirement) }\end{array}$ & Recent major life event \\
\hline Aida & Female, 63 & Educator & Retirement, death of both parents \\
\hline Anne & Female, 75 & Business owner & Major personal illness \\
\hline Annette & Female, 68 & Worker & Death of spouse \\
\hline Antoine & Male, 88 & Sailor & Major personal illness \\
\hline Antoinette & Female, 65 & Worker & Death of spouse \\
\hline Bernard & Male, 76 & Engineer & Major personal illness \\
\hline Catherine & Female, 71 & Manager & Death of spouse \\
\hline Claire & Female, 76 & Housewife & Death of spouse \\
\hline Claude & Male, 63 & Town hall employee & Retirement, major personal illness \\
\hline Denise & Female, 68 & Executive secretary & Death of spouse \\
\hline Edith & Female, 72 & Employee & Death of spouse \\
\hline Elise & Female, 62 & Manager & Death of spouse \\
\hline Eloise & Female, 75 & Craftsman & Death of spouse \\
\hline Evelyne & Female, 61 & Employee & Death of spouse \\
\hline Geneviève & Female, 72 & Nurse & Death of spouse \\
\hline Gisèle & Female, 67 & Schoolteacher & Death of spouse \\
\hline Jacqueline & Female, 60 & Nurse & Retirement, death of family member \\
\hline Jean & Male, 71 & Manufacturer & Major personal illness \\
\hline Jeanine & Female, 74 & Farmer & Death of spouse \\
\hline Jeanne & Female, 79 & Farmer & Death of spouse \\
\hline Jeannette & Female, 75 & Employee & Change in health, illness of close family member \\
\hline Jocelyne & Female, 74 & Cleaner & Death of spouse \\
\hline Joelle & Female, 78 & Housewife & Death of a close friend \\
\hline Karine & Female, 69 & Child minder & Death of spouse \\
\hline Line & Female, 58 & Child minder & Death of spouse \\
\hline Marion & Female, 67 & Manager & Death of spouse \\
\hline Martine & Female, 81 & Housewife & Death of spouse \\
\hline Nathalie & Female, 56 & Cleaner & Death of spouse \\
\hline Paul & Male, 60 & Doctor & Retirement, divorce \\
\hline Paulette & Female, 74 & Accountant & Death of spouse \\
\hline Pierre & Male, 82 & SSH researcher & Major personal illness \\
\hline Serge & Male, 60 & Farmer & Retirement, last child to leave home \\
\hline Simone & Female, 65 & Manager & Death of spouse \\
\hline Sylvie & Female, 63 & Librarian & $\begin{array}{l}\text { Retirement, death of both parents, last child to } \\
\text { leave home }\end{array}$ \\
\hline Therese & Female, 81 & Housewife & Death of close family member \\
\hline Yvette & Male, 60 & Housewife & Retirement, last child to leave home \\
\hline Yvonne & Female, 64 & Tradeswoman & Death of spouse \\
\hline
\end{tabular}

